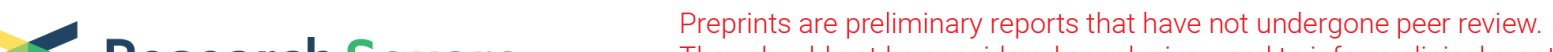 $\begin{array}{ll}\text { Research Square } & \text { They should not be considered conclusive, used to inform clinical practice, } \\ \text { or referenced by the media as validated information. }\end{array}$
}

\section{Big Data Palaeoecology reveals significant variation in Black Death mortality in Europe}

Adam Izdebski

Max Planck Institute for the Science of Human History

\section{Piotr Guzowski}

University of Bialystok https://orcid.org/0000-0002-6494-4217

\section{Radosław Poniat}

Faculty of History and International Relations, University of Bialystok

\section{Lucrezia Masci}

Department of Earth Science, Sapienza University of Rome

\section{Jordan Palli}

Dendrologylab, Department of Agriculture and Forest Sciences (Dafne), University of Tuscia

\section{Cristiano Vignola}

Department of Environmental Biology, Sapienza University of Rome

\section{Martin Bauch}

Leibniz Institute for the History and Culture of Eastern Europe (GWZO)

\section{Carlo Cocozza}

Max Planck Institute for the Science of Human History

\section{Ricardo Fernandes}

Max Planck Institute for the Science of Human History

\section{Fredrik Ljungqvist}

Stockholm University https://orcid.org/0000-0003-0220-3947

\section{Timothy Newfield}

Georgetown University https://orcid.org/0000-0003-1451-5024

\section{Andrea Seim}

Chair of Forest Growth, Institute of Forest Sciences, Albert Ludwig University of Freiburg

\section{Daniel Abel-Schaad}

Department of Botany, Faculty of Sciences, Universidad de Granada https://orcid.org/0000-0003-39158342

\section{Francisca Alba-Sánchez}

Department of Botany, Faculty of Sciences, Universidad de Granada https://orcid.org/0000-0003-03871533

\section{Leif Björkman}

Viscum Pollenanalys \& Miljöhistoria

\section{Achim Brauer}


Helmholtz-Zentrum Potsdam Deutsches GeoForschungsZentrum GFZ

\section{Alex Brown}

Wessex Archaeology, Portway House

\section{Sambor Czerwiński}

Climate Change Ecology Research Unit, Adam Mickiewicz University

\section{Ana Ejarque}

CNRS, Université Clermont Auvergne, GEOLAB

\section{Magdalena Fiłoc}

Department of Palaeobiology, Faculty of Biology, University of Białystok https://orcid.org/0000-00031226-2676

\section{Assunta Florenzano}

Laboratory of Palynology and Palaeobotany, Department of Life Sciences, University of Modena and Reggio Emilia

\section{Erik Fredh}

Museum of Archaeology, University of Stavanger

\section{Ralph Fyfe}

University of Plymouth

\section{Nauris Jasiunas}

Department of Geography, University of Latvia

\section{Piotr Kołaczek}

Climate Change Ecology Research Unit, Adam Mickiewicz University

\section{Katerina Kouli}

National and Kapodistrian University of Athens https://orcid.org/0000-0003-1656-1091

\section{Radka Kozáková}

Institute of Archeology, Academy of Sciences of the Czech Republic

\section{Mirosława Kupryjanowicz}

Department of Palaeobiology, Faculty of Biology, University of Białystok

\section{Per Lagerås}

The Archaeologists, National Historical Museums

\section{Mariusz Lamentowicz}

Climate Change Ecology Research Unit, Adam Mickiewicz University

\section{Matts Lindbladh}

Southern Swedish Forest Research Centre, Swedish University of Agricultural Sciences Jose Antonio López-Sáez

CSIC

\section{Reyes Luelmo-Lautenschlaeger}

Environmental Archaeology Research Group, Institute of History, CSIC

\section{Katarzyna Marcisz}


Climate Change Ecology Research Unit, Adam Mickiewicz University https://orcid.org/0000-0003-26559729

\section{Florence Mazier}

Department of Environmental Geography, GEODE UMR 5602, Jean Jaurès University

\section{Scott Mensing}

Department of Geography

\section{Anna Maria Mercuri}

Università di Modena e Reggio Emilia https://orcid.org/0000-0001-6138-4165

\section{Krystyna Milecka}

Anthropocene Research Unit, Faculty of Geographical and Geological Sciences, Adam Mickiewicz University

\section{Yannick Miras}

CNRS, HNHP UMR 7194, Muséum National d'Histoire Naturelle, Institut de Paléontologie Humain

\section{Agnieszka Noryśkiewicz}

Institute of Archaeology, Faculty of History, Nicolaus Copernicus University

\section{Elena Novenko}

Faculty of Geography, Lomonosov Moscow State University

\section{Milena Obremska}

Institute of Geological Sciences, Polish Academy of Sciences

\section{Anna Pędziszewska}

Laboratory of Palaeoecology and Archaeobotany, Department of Plant Ecology, Faculty of Biology, University of Gdańsk

\section{Sebastián Pérez-Díaz}

Department of Geography, Urban and Regional Planning, Universidad de Cantabria

\section{Gianluca Piovesan}

Università della Tuscia https://orcid.org/0000-0002-3214-0839

\section{Aleks Pluskowski}

University of Reading https://orcid.org/0000-0002-4494-7664

\section{Petr Pokorný}

Charles University in Prague

\section{Anneli Poska}

Department of Geology, Tallinn University of Technology

\section{Triin Reitalu}

Department of Geology, Tallinn University of Technology

\section{Manfred Rösch}

Department of Prae- and Early History and West Asian Archaeology, University of Heidelberg

\section{Laura Sadori}

Sapienza Università di Roma https://orcid.org/0000-0002-2774-6705

\section{Carla Sá Ferreira}


School of Natural and Built Environment, Queen\&\#39;s University Belfast

\section{David Sebag}

University of Rouen https://orcid.org/0000-0002-6446-6921

\section{Michał Słowiński}

Institute of Geography and Spatial Organization Polish Academy of Sciences https://orcid.org/00000002-3011-2682

\section{Migle Stančikaitè}

Institute of Baltic Region History and Archaeology, University of Klaipėda

\section{Normunds Stivrins}

Department of Geography, University of Latvia

\section{Irene Tunno}

Center for Accelerator Mass Spectrometry (CAMS), Lawrence Livermore National Laboratory

\section{Siim Veski}

Department of Geology, Tallinn University of Technology

\section{Agnieszka Wacnik}

W. Szafer Institute of Botany, Polish Academy of Sciences

\section{Alessia Masi ( $\square$ alessia.masi@uniroma1.it)}

Sapienza University of Rome https://orcid.org/0000-0001-9822-9767

\section{Article}

Keywords: Pandemic, Ancient DNA Research, Bacterium Yersinia Pestis, Landscape Change, Interregional Differences

Posted Date: July 2nd, 2021

DOl: https://doi.org/10.21203/rs.3.rs-581474/v1

License: (c) (7) This work is licensed under a Creative Commons Attribution 4.0 International License. Read Full License

Version of Record: A version of this preprint was published at Nature Ecology \& Evolution on February 10th, 2022. See the published version at https://doi.org/10.1038/s41559-021-01652-4. 


\section{Abstract}

The Black Death is the most reknown pandemic in human history, believed by many to have killed half of Europe's population. However, despite the advances in ancient DNA research that allowed for the successful identification of the pandemic's causative agent (bacterium Yersinia pestis), our knowledge of the Black Death is still limited, based primarily on medieval texts available for single areas of Western Europe. In our study we remedy this situation and we focus in particular on the scale of the Black Death mortality. We collected data on landscape change from 261 coring sites (lakes and wetlands) located in 19 European countries. We used two independent methods of analysis to evaluate whether the changes we see in the landscape at the time of the Black Death agree with the hypothesis that half of the population died within a single year in each of the 21 regions we studied. We discovered that while the Black Death had devastating impact in some regions, it had negligible or no impact in others. The interregional differences in the Black Death mortality across Europe demonstrate the significance of cultural, ecological, economic and climatic factors that mediate the dissemination and impact of the disease. The complex interplay of these factors, along with the identification of the pathogen that caused disease outbreaks, should be the focus of future research on historical pandemics.

\section{Summary Paragraph}

Few doubt the mid-14th-century Afro-Eurasian plague pandemic, the Black Death, killed tens of millions of people. In Western Asia and Europe, where its spread and mortality are best understood, upwards of $50 \%$ of the population is thought to have died within $\sim 5$ years. ${ }^{1-4}$ Whole-genome sequencing confirms the pandemic as a novel introduction of the zoonotic bacterium Yersinia pestis. 5,6 Yet, despite advances in paleogenetics and generations of written-source-based research on the cultural and economic transformations plague is credited with accelerating, from the 'Great Divergence' to the Renaissance 7,8 , much about the Black Death's demographic impact remains poorly understood. The regionality of the plague's mortality is particularly underexplored, owing to the availability of written sources and the limits of traditional historical methods. Here we pioneer a new approach, Big Data Palaeoecology (BDP), that leverages the field of palynology to evaluate the demographic impact of the Black Death on a regional scale across Europe, independent of written sources. Our analysis of 1,634 pollen samples from 261 sites, reflecting landscape change and agricultural activities, demonstrates Black Death mortality was far more spatially heterogenous then previously recognised. Strikingly, BDP provides independent confirmation of the devastating toll historical sources evidence of the Black Death in some European regions, while establishing conclusively for the first time that the Black Death did not affect all regions equally. We attribute this mortality variation to climatic, cultural, ecological, economic and societal factors, which influenced $Y$. pestis dissemination and prevalence, generating regionally unique outcomes.

\section{Estimating Black Death Mortality}

Multidisciplinary studies are redefining the Black Death. In recent years, paleogeneticists have confirmed the pandemic's $Y$. pestis identity and established that the outbreak seeded novel plague reservoirs in 
Europe $^{5,6}$. Archeologists and historians meanwhile have begun to put Sub-Saharan Africa on the Black Death map ${ }^{9}$, to fill in lacunae in our understanding of the pandemic's Mediterranean and European $\operatorname{spread}^{10,11}$, and to explore the pandemic's origins in Central Asia and dissemination in East Asia, drawing on evolutionary biology and paleogenetics ${ }^{12}$. But while multiple disciplines have reassessed the pandemic's spatiotemporality, the mortality of the outbreak, estimates of which have drawn attention to the Black Death for centuries, remains underexplored and limited to unidisciplinary, written-source-based approaches.

Medieval mortality data are scarce and highly fragmentary. 19th -c. historians of the Black Death based their assertion that the pandemic claimed $25 \%$ or more of European lives on assessments of qualitative narrative sources ${ }^{13}$. Since the mid-20th c., historians have painstakingly built-up multiple more instructive case studies of Black Death mortality for regions comparatively well-endowed with administrative sources allowing for statistical analysis (e.g., regions of England, France, Italy, the Netherlands) ${ }^{14-16}$. Some of these cases studies have argued for a death toll in the range of $50 \%$ or more. These studies have been increasingly considered representative of the Black Death's broader mortality, and employed as proxies for Black Death mortality in European regions where direct evidence for the pandemic is nonexistent (e.g. Bohemia, Finland), slight (single sentences or vague passages: e.g. Moravia, Hungary and Scotland), or available but neither detailed nor quantitative (most regions, including areas of England, France, Italy, the Netherlands) ${ }^{1}$.

By treating case studies of relatively well-documented regions as predictive of the pandemic's death toll in all regions the pandemic touched, histories of the Black Death implicitly rest on the untested assumption that plague mortality was uniform across regions regardless of local cultural, ecological, economic, and societal contexts, and therefore that the prevalence of $Y$. pestis, an ecologically and epidemiologically complex disease ${ }^{17}$, was comparable across Europe. This methodology has lent itself to estimates of an aggregate European death toll of $\sim 50 \%$ ( 50 million deaths $)^{1,4}$, though studies accounting for regional source scarcities have estimated mortality to have fallen below that mark $8,18,19$. Problematically, most of the quantitative sources drawn upon to build cases studies of Black Death mortality relate to urban contexts, which owing to their crowding and generally poor sanitation may have suffered higher plague mortality than rural areas ${ }^{20,21}$, and in the mid-14th -c. upwards of $75-95 \%$ of the population of all European regions was rural ${ }^{22}$. Although every pandemic, plague or not, is distinct, a Black Death mortality of 50\% far exceeds the demographic losses sustained during the late-19th -c. third plague pandemic, including China and India which were then severely affected ${ }^{23,24}$.

\section{Big-data Palaeoecology (B D P) And Black Death Mortality}

Here we pioneer an alternative approach (discussed in detail in Methods). BDP allows us to evaluate Black Death mortality across Europe using quantitative paleoenvironmental datasets which can be employed for spatial statistical comparisons. Our dataset consists of fossil pollen counts from 261 radiocarbon-dated sediment cores from 19 present-day European countries (Fig. 1; Supplementary Data 
1). Pollen data can be used to assess past demographic dynamics as human pressure on the landscape in the preindustrial period was directly dependent on the availability of rural labour. We focus on the period between 1250 and $1450 \mathrm{CE}$ for which 1,634 pollen-analysed sediment samples are available (Supplementary Data 2). In order to compare trends between different European bioclimatic zones, we assembled pollen types (taxa) representing different plants from species to family level into four standardised summary indicators, based on their subsistence value for human economy or their ecological needs as reflected in two major ecological indices, the Ellenberg light indicator and Niinemets and Valladares shade tolerance scale: (1) Cereals; (2) Herding (pasturelands); (3) Fast forest secondary succession (pioneer shrubs and trees growing on former fields/pastures within 5-10 years of abandonment); (4) Slow forest secondary succession (mature-late successional woodland on abandoned fields/pastures). We discuss the results of the Ellenberg-based indicators below, but the Niinemets-based indicators yielded the same results in 19 out of 21 regions and the differences do not bear on our discussion (Extended Data Figs. 1 and 2).

\section{Validity Test: Sweden And Poland}

We validated our BDP approach by examining two well-studied, but contrasting, regional case studies of Black Death mortality, in Sweden and Poland. An earlier multi-disciplinary analysis discovered significant contraction in cereal cultivation, as well as a more general economic and demographic decline, in Southern Sweden following the Black Death ${ }^{25}$. In contrast, historians have long demonstrated that Central Europe, Poland particularly, experienced economic growth over the 14th c. ${ }^{26}$ Our BDP approach independently corroborates these trajectories. We validate the ability of our pollen datasets to reflect the extent of Black Death mortality by comparing them to historical data of national tax payments made to the pope (Peter's Pence) ${ }^{27-29}$ (Extended Data Fig. 3).

\section{Landscape And Demographic Change: Four Major Scenarios}

Having validated our approach, we analysed the pollen dataset for all of Europe. We focused on contrasting the four summary pollen indicator values on a regional scale for sub-periods of 100 years before and after the Black Death. We discuss the results of this analysis here (Fig. 2); we also present our complimentary 50-year (1301-1350 to 1351-1400) and 25-year (1325-1350 to 1351-1375) analyses (Extended Data Figs. 4 and 5). For cereals, they returned the same results for 20 out of 21 regions for 50year and 15 out of 19 regions for 25 -year analyses, confirming the robustness of our conclusions.

BDP employs bootstrapping for evaluating statistical significance of the differences between the pre- and post-Black Death sub-periods on a regional level. In this way, we identified four scenarios of post-Black Death agricultural change based on the cereal pollen indicator (Fig. 2): (1) substantial and statistically significant increase, reflecting arable expansion and limited Black Death mortality (top panel); (2) modest and statistically insignificant increase, suggesting stability or slow-paced agrarian growth (upper middle panel); (3) modest and statistically insignificant decrease, suggesting stagnation or some contraction of agrarian activities, possibly stemming from more limited demographic losses or economic disruption 
caused by the plague (lower middle panel); (4) substantial and statistically significant decrease, reflecting arable contraction and pronounced Black Death mortality (bottom panel). Scenarios 1 and 2 falsify the theory that Black Death mortality was everywhere significant. Scenario 3 and 4 demonstrate Black Death mortality was devastating in some regions, but that the extent of the mortality varied regionally.

Changes in the herding indicator reveal trajectories similar to those of cereals in most cases or no change. We discovered only one region (SW Germany) where there occurred a statistically significant decline in cultivation in parallel with a statistically significant increase in herding (some indication of this is also apparent in Greece), suggesting a shift to livestock production related to agrarian labour shortages ${ }^{30}$. The fast forest succession indicator increases in a statistically significant way in Central Italy and Central France, confirming field abandonment. In Central Italy, this is accompanied by discernible reforestation (statistically significant increase in the slow forest succession indicator), attesting to significant regional Black Death mortality and slow demographic and economic recovery.

To confirm the robustness of our results, BDP combines statistical with independent spatial approaches (Fig. 3). The latter yielded results identical for all four BDP indicators to our statistical approach in our 100-year period analysis and for our 50-year (1301-1350 to 1351-1400) and 25-year (1325-1350 to 1351-1375) period analyses (Extended Data Fig. 7-10).

\section{Black Death: A Diverse And Entangled Phenomenon}

Figure 4 visualizes the spatial distribution of the four trajectories of post-Black Death landscape change from Fig. 2, demonstrating that Black Death mortality varied significantly between European regions. The pandemic was immensely destructive in some areas, but in others it had a far lighter touch. Strikingly, BDP identifies a sharp agricultural decline in several regions of Europe, independently corroborating analyses of historical sources that suggest high mortality in regions of Scandinavia, France, Western Germany, Greece, and Central Italy ${ }^{1}$ and lending further validation to our approach. At the same time, there is much evidence for continuity and uninterrupted agricultural growth in Central and Eastern Europe, and several regions of Western Europe, particularly in Ireland and Iberia. In this way, BDP complicates histories of the Black Death that assume Y. pestis was uniformly prevalent across Europe and that the pandemic everywhere had a devastating demographic impact.

The significant variability of Black Death mortality that our BDP approach identifies remains to be explained, but local cultural, demographic, economic, environmental and societal contexts likely influenced $Y$. pestis prevalence, morbidity and mortality. The spread of the pandemic depended on numerous factors, which would have generated compound effects, feedback loops, and regionally unique outcomes. Plague is an ecologically and epidemiologically complex zoonotic disease, maintained by sylvatic rodents and their fleas, and transmittable to and between people via multiple pathways, including commensal and sylvatic rodent flea bites, respiratory secretions, direct contact with infected animals, human ectoparasites (fleas and lice), and fomites ${ }^{17}$. The behaviour of $Y$. pestis hosts and vectors, and their capacity to efficiently transmit the pathogen, is partly constrained by complex interactions with 
seasonal climate variability and local ecological conditions, both in anthropogenic and rural environments (cities, villages and fields vs. mountains, forests or wetlands ${ }^{31}$ ). Regional variation in population density and distribution, ectoparasite burdens, living conditions, and commensal rodent populations and their fleas, undoubtedly mattered. Local climatic contexts were shown to have strongly determined third plague pandemic dynamics in $\mathrm{Asia}^{32,33}$. In Europe, where the Black Death spread over several years (1347-1352 for the regions considered here), different seasons and annually variable climatic conditions may have influenced $Y$. pestis prevalence and the pandemic's mortality. Further, while hypothesized links between early-14th-c. famines and the Black Death remain to be substantiated, and while $Y$. pestis is often lethal ${ }^{17}$, it has been shown Black Death mortality was selective and the immunological and nutritional heterogeneity of the populations the pathogen interacted with would have ensured uneven toll ${ }^{34,35}$.

That climatic, cultural, ecological and economic factors shaped regional Black Death outcomes is wellillustrated by the initial phases of the pandemic in Europe. Cereal trade is thought to have been instrumental for the introduction of the Black Death to Mediterranean Europe, and along established conduits of commerce and communication, ecological factors, associated contingency effects and historical path dependency mattered from the outset. Before the pandemic arrived in the Crimea, the volume of cereal trade between Italy and the Black Sea was sizeable, yet blocked by embargo ${ }^{11,36,37}$. High demand in Southern Europe for Black Sea cereals from 1345 onwards was associated with a period of excessive precipitation and cooling ${ }^{38,39}$ negatively affecting cereal supplies in Italy and beyond, 1345$47^{8,36,40,41}$. Cereal imports from Black Sea coasts resumed once the situation improved in 1347, and by early 1348 Venetian merchants had filled many Italian granaries with Black Sea produce $11,36,37,42$ and introduced plague to Europe. Plague outbreaks disseminated from major cereal ports in southern and north-western Italy from January $1348^{1,43}$. To the contrary, plague hardly spread in north-western Italy, which was independent from overseas cereal imports ${ }^{36,42,44}$. Local circumstances were shaping the outcome of the pandemic on regional scales from the outset.

To conclude, our BDP approach shows Black Death mortality was far more spatially heterogeneous than previously thought. This significant variation in Black Death mortality may be explained by the pathogen's entanglement with a dynamic nexus of climatic, cultural, demographic, ecological and societal factors that determined its prevalence and the pandemic's mortality in any given region. That the pandemic was immensely destructive in some regions, but not all, falsifies the practice, common in Black Death studies, of predicting one region's experience on the basis of another's. Regional mortality outcomes must be reconstructed using local sources, including BDP. As a few well-documented case studies of destructive Black Death mortality in Europe have informed estimates of Black Death mortality not only in other European regions, but also in several regions of Africa and Asia, our findings have significant implications both for the wider history of the Black Death and for how historical disease outbreaks are reconstructed.

\section{Declarations}




\section{Acknowledgements}

The authors acknowledge the following funding sources: Estonian Research Council \# PRG323, PUT1173 (AP, TR, NS SV); European Research Council \# FP7 263735 (AB, AP), \# MSC 655659 (AE); Georgetown Environmental Initiative (TN); Latvian Council of Science \# LZP-2020/2-0060 (NS, NJ); LLNL-JRNL820941 (IT); NSF award \# GSS-1228126 (SM); Polish-Swiss Research Programme \# 013/2010 CLIMPEAT (ML), \# 086/2010 CLIMPOL (AW); Polish Ministry of Science and Higher Education \# N N306 275635 (MK); Polish National Science Centre \# 2019/03/X/ST10/00849 (ML), \# 2015/17/B/ST10/01656 (ML),\# 2015/17/B/ST10/03430 (MS), \# 2018/31/B/ST10/02498 (MS), \# N N304 319636 (AW); SCIEX \# 12.286 (KM); Spanish Ministry of Economy and Competitiveness \# REDISCO-HAR2017-88035-P (JALS); Spanish Ministry of Education, Culture and Sports \# FPU16/00676 (RLL); Swedish Research Council \# 421-2010-1570 (PL), \# 2018-01272 (FCL, AS); Volkswagen Foundation Freigeist Fellowship Dantean Anomaly (MB).

\section{Author contributions}

$A l, A M$ and $P G$ designed the study. Al drafted the paper with contributions from MB, RF, AM, TN, PG, RP, and CV. AM, LM, JP and CV created the pollen database, with the support of JALS (Spain), PL (Sweden), and TR (Estonia). Al, RP, RF and CC carried out the analyses. All other authors provided palynological data and contributed to the text and the interpretation.

\section{Competing interests}

The authors declare no competing interests.

\section{Materials \& Correspondence}

Please address your inquiries to Alessia Masi, alessia.masi@uniroma1.it, and Adam Izdebski, izdebski@shh.mpg.de

\section{References}

1.

Benedictow, O. L. The Black Death 1346-1353: the complete history. (Boydell, 2004).

2.

Mohammed, M. Peste, contagion et martyre: Histoire du fléau en Occident médiéval. (Publisud, 2005). 
Varlik, N. Plague and empire in the early modern Mediterranean world: the Ottoman experience, 13471600. (Cambridge University Press, 2015).

4.

Aberth, J. The Black Death: a new history of the great mortality in Europe, 1347-1500. (Oxford University Press, 2021).

5.

Bos, K. I. et al. A draft genome of Yersinia pestis from victims of the Black Death. Nature 478, 506-510 (2011).

6.

Spyrou, M. A. et al. Phylogeography of the second plague pandemic revealed through analysis of historical Yersinia pestis genomes. Nat Commun 10, 1-13 (2019).

7.

Herlihy, D. Climate and Documentary Sources: A Comment. The Journal of Interdisciplinary History 10, 713-717 (1980).

8.

Campbell, B. The Great Transition: Climate, Disease and Society in the Late-Medieval World. (Cambridge University Press, 2016).

9.

Chouin, G. L. Reflections on plague in African history (14th-19th c.). Afriques 9, 2228 (2018).

10.

Roosen, J. \& Curtis, D. R. Dangers of Noncritical Use of Historical Plague Data. Emerging Infectious Diseases 24, 103-110 (2018).

11.

Barker, H. Laying the Corpses to Rest: Grain, Embargoes, and Yersinia pestis in the Black Sea, 1346-48. Speculum 96, 97-126 (2020).

12. 
Green, M. The Four Black Deaths. American Historical Review 125, 1601-1631 (2020).

13.

Hecker, J. Der schwarze Tod. (1832).

14.

Hatcher, J. Plague, population, and the English economy, 1348-1530. (Macmillan, 1977).

15.

Ormrod, W. M. \& Lindley, P. G. The Black Death in England, 1348-1500. (Paul Watkins, 1996).

16.

Roosen, J. \& Curtis, D. R. The 'light touch' of the Black Death in the Southern Netherlands: an urban trick? The Economic History Review 72, 32-56 (2019).

17.

Dubyanskiy, V. M. \& Yeszhanov, A. B. Ecology of Yersinia pestis and the Epidemiology of Plague. in Yersinia pestis: Retrospective and Perspective (eds. Yang, R. \& Anisimov, A.) 101-170 (Springer Netherlands, 2016). doi:10.1007/978-94-024-0890-4_5.

18.

Gottfried, R. S. The Black Death: natural and human disaster in medieval Europe. (Robert Hale, 1983).

19. Christakos, G. Interdisciplinary public health reasoning and epidemic modelling: the case of Black Death. (Springer, 2005).

20.

Olea, R. A. \& Christakos, G. Duration of urban mortality for the 14th-century Black Death epidemic. Hum Biol 77, 291-303 (2005).

21.

Alfani, G. Plague in seventeenth-century Europe and the decline of Italy: an epidemiological hypothesis. European Review of Economic History 17, 408-430 (2013).

22.

Neithard, B. L'essor (Xe - XIVe siècle). in Histoire des populations de l'Europe (eds. Dupâquier, J. \& Bardet, J.-P.) vol. 1: Des origines aux prémices de la révolution démographique 168-184 (Fayard, 1997). 
23.

Echenberg, M. Plague Ports: The Global Urban Impact of Bubonic Plague,1894-1901. (NYU Press, 2007).

24.

Tumbe, C. Pandemics and Historical Mortality in India.

https://web.iima.ac.in/assets/snippets/workingpaperpdf/17719931472020-12-03.pdf (2020).

25.

Lagerås, P. et al. Abandonment, agricultural change and ecology. in Environment, society and the Black Death: an interdisciplinary approach to the late-medieval crisis in Sweden (ed. Lagerås, P.) 30-68 (Oxbow Books, 2016).

26.

Małowist, M. Western Europe, Eastern Europe and world development, 13th-18th centuries: collection of essays of Marian Małowist. (Brill, 2010).

27.

Guzowski, P., Kuklo, C. \& Poniat, R. O metodach pomiaru natężenia epidemii i zaraz w preindustrialnej Europie w demografii historycznej. in Epidemie w dziejach Europy: konsekwencje społeczne, gospodarcze i kulturowe (eds. Polek, K. \& Sroka, Ł. T.) 119-144 (Wydawnictwo Naukowe Uniwersytetu Pedagogicznego, 2016).

28.

Myrdal, J. The forgotten plague: the Black Death in Sweden. in When disease makes history: epidemics and great historical turning points (ed. Hämäläinen, P.) 141-186 (Helsinki University Press, 2006).

29.

Myrdal, J. The Black Death in the North. in Living with the Black Death (eds. Bisgaard, L. \& Søndergaard, L.) 63-84 (University Press of Southern Denmark; Gazelle [distributor, 2011).

30.

Poos, L. Rural Society after the Black Death. (Cambridge University Press, 2011).

31.

Slavin, P. Out of the West: formation of a permanent plague reservoir in South-Central Germany (13491356) and its implications. Past \& Present gtaa028 (2021) doi:10.1093/pastj/gtaa028. 
$\mathrm{Xu}, \mathrm{L}$. et al. Nonlinear effect of climate on plague during the third pandemic in China. PNAS 108, 1021410219 (2011).

33.

$\mathrm{Xu}, \mathrm{L}$. et al. Wet climate and transportation routes accelerate spread of human plague. Proc Biol Sci 281, 20133159 (2014).

34.

DeWitte, S., Stature and frailty during the Black Death: the effect of stature on risks of epidemic mortality in London, A.D. 1348-1350. J Arch Sci 39, 1412-1419 (2012).

35.

Crespo, F. \& Lawrenz, M.B., Heterogeneous Immunological Landscapes and Medieval Plague: An Invitation to a New Dialogue between Historians and Immunologists. The Medieval Globe 1, 229-258 (2014).

36.

Pinto, G. Firenze e la carestia del 1346-47: Aspetti e problemi delle crisi annonarie alla metà del '300. Archivio Storico Italiano 130, 3-84 (1972).

37.

Faugeron, F. Nourrir la ville: ravitaillement, marchés et métiers de l'alimentation à Venise dans les derniers siècles du Moyen Âge. (2014).

38.

Luterbacher, J. et al. European summer temperatures since Roman times. Environ. Res. Lett. 11, 024001 (2016).

39.

Esper, J. et al. Eastern Mediterranean summer temperatures since 730 CE from Mt. Smolikas tree-ring densities. Clim Dyn 54, 1367-1382 (2020).

40.

Campbell, B. The European Mortality Crises of 1346-52 and Advent of the Little Ice Age. in Famines During the \Little Ice Age' (1300-1800) Socionatural Entanglements in Premodern Societies 19-41 (Springer, 2017). 
Bauch, M. \& Engel, A. Die 1340er Jahre als Schlüsseljahrzehnt der ,Great Transition'. Eine klimahistorische Perspektive auf den Vorabend des Schwarzen Todes. in Pest! Sonderausstellung des LWL-Museums für Archäologie - Westfälisches Landesmuseum Herne (eds. Berner, A., Leenen, S. \& Maus, S.) 76-82 (WBG, 2019).

42.

Hübner, H.-J. Quia bonum sit anticipare tempus. Die kommunale Versorgung Venedigs mit Brot und Getreide vom späten 12. bis ins 15. Jahrhundert. (Lang, 1998).

43.

Del Panta, L. Le epidemie nella storia demografica italiana. (secoli XIV-XIX). (Loescher, 1980).

44.

Santoro, C. Gli offici del Comune di Milano e del Dominio visconteo-sforzesco <1216-1515>. (Giuffrè, 1968).

\section{Methods}

\section{Big Data Palaeoecology (BDP) approach: pollen-inferred landscape change and preindustrial demography}

Recently, paleoenvironmental data derived from tree rings or ice cores have been employed to approximate changes in human economic activity related to past epidemics, as well as to warfare and climatic variability ${ }^{45,46}$. However, none of these proxies is directly related to human demography or provides a basis to estimate variation in Black Death mortality on a regional scale across Europe.

On the contrary, in preindustrial economies, rural labour availability and the spatial scale of cereal cultivation were directly related. An increase in the extent and intensity of cereal cultivation - as reflected in pollen data - would have required not only a predilection and demand for cereals, but greater availability of labour and thus population growth or significant immigration. The maintenance of existing agricultural activity, in turn, would have required relatively stable population levels. ${ }^{4-49}$ The uniform $\sim 50 \%$ mortality postulated for the Black Death across Europe should have resulted in a large and significant decline of cereal cultivation and parallel forest regrowth across Europe, as previously demonstrated for mid- $14^{\text {th }} \mathrm{c}$. Sweden ${ }^{25}$ and singular sites in some regions of Western Europe ${ }^{50}$. This result agrees with the fact that Black Death mortality could be high among people at productive age, as illustrated for England ${ }^{51,52}$. Moreover, even in the case of England, a comparatively commercialised and adaptive rural economy in mid- $14^{\text {th }}$-c. Europe, the loss of $50 \%$ of population led to a significant decline in the total area under cultivation (as documented by heterogeneous written sources) ${ }^{53}$. In Italy, another 
well-developed economy at that time, the expansion of large estates following the Black Death also did not compensate for the general loss of cereal productivity ${ }^{54}$. This effect, high mortality driving arable contraction, must have been yet more pronounced in more subsistence-oriented and less adaptive economies, with limited surplus production, such as in regions of the Iberian Peninsula, Germany, Sweden, and particularly East-Central Europe. Importantly, palaeoecological evidence for arable contraction may be indicative, to some extent, of not only rural population decline but also urban population decline in the region, as there is evidence in some areas, following the pandemic, of rural-tourban migration, of country-dwellers repopulating urban centres ${ }^{10}$. Possibly less common was intraregional rural migration, as marginal lands were abandoned for better quality soils, which were more likely to remain under cultivation 25,55 .

\section{BDP data collection}

Existing online palynological databases (the European Pollen Database (EPD) ${ }^{56}$ www.europeanpollendatabase.net, and the Czech Quaternary Palynological Database $(\mathrm{PALYCZ})^{57}$, https://botany.natur.cuni.cz/palycz/), as well as personal contacts of the study authors and a systematic publication search were employed to identify palynological sites in Europe reaching the required chronological and resolution quality for the study of the last millennium. In order to enable statistical analysis, we included only sites clustered in well-defined historical-geographical regions, excluding isolated sites even if the quality of a site's data was very good. Data of sufficient quality and amount from regions for which the Black Death is well-studied, notably Central and Northern England and the Low Countries, is not presently available; to the best of our knowledge, for each of these regions there currently is not more than a single isolated site ${ }^{50}$, which does not allow for the application of statistical approaches.

In total, 261 pollen records with the average temporal resolution of 58 years and ${ }^{14} \mathrm{C}$-age control (or varve chronology), have been collected. The age-depth models of the sequences have been provided by authors in original publications, by the EPD or developed through the Clam package (version 2.3.4) of R software for the purpose of this study. The analytical protocol for pollen extraction and identification is reported in the original publications. The Pollen Sum includes all the terrestrial taxa with some exceptions based on the selection done in the original publications. The full list of sequences, exclusions from the Pollen Sum, age-depth models and full references are reported in Supplementary Data 1.

The taxa list has been normalized by applying the EPD nomenclature. In this respect, the general name Cichorioideae includes Asteraceae subf. Cichorioideae of the EPD and PALYCZ nomenclatures, which primarily refers to the fenestrate pollen of the Cichorieae tribe ${ }^{58}$. Ericaceae groups Arbutus unedo, Calluna vulgaris, Vaccinium and different Erica pollen types, whereas deciduous Quercus comprehends both $Q$. robur and $Q$. cerris pollen types ${ }^{59}$. Rosaceae refers to both tree and herb species of the family. Finally, Rumex includes $R$. acetosa type, $R$. acetosella, $R$. crispus type, Rumex/Oxyria and Urtica groups U. dioica type and U. pilulifera. 


\section{BDP summary pollen indicators}

In order to connect changes visible in the pollen data to human demographic trajectories, we assembled four summary pollen indicators that describe specific landscapes related to human activity. They reflect different degrees of demographic pressure on the landscape (cereal cultivation, pastoral activities, which are less-labour intensive than cereal cultivation, abandonment and rewilding) as well as different durations of land abandonment that might have occurred post-Black Death. Our indicators account for the fact that Europe is a continent rich in natural heritage, with a wide range of landscapes and habitats and a remarkable wealth of flora and fauna, shaped by climate, geomorphology and human activity. In order to ensure uniform interpretation of the indicators, we relied on criteria that can be applied to all European landscapes regardless of their local specificity. Cereals and herding are directly related to human activities and are barely influenced by spatial differences. More complex is the succession of natural plants with their ecological behaviour and inter-species competition. For this reason, we relied on existing quantitative indicators of plant ecology.

The Ellenberg $L$ - light availability indicator ${ }^{60}$ provides a measure of sunlight availability in woodlands and consequently of tree-canopy thickness, reflecting the scale of the natural regeneration of woodland vegetation after cultivation or pasture activities ${ }^{61}$. Nonetheless, ecological studies have suggested that geographic and climatic variability between different European regions can influence the Ellenberg indicator system ${ }^{62-65}$. The original indicators were primarily designed for Central Europe ${ }^{58}$, but several studies developed Ellenberg indicators for other regions, reflecting the specific ecology of the selected taxa (British Isles ${ }^{66}$; Czech Republic ${ }^{67}$; Greece ${ }^{68}$; Italy ${ }^{69}$; Sweden ${ }^{70}$ ). Plants with a $L$ values between 5 and 8 are listed in fast succession indicator, the ones with $L$ values ranging from 1 to 4 are included in slow succession indicator. The result is the following list:

1) Cereals: only cultivated cereals have been included: Avena/Triticum type, Cerealia type, Hordeum type, Secale. 2) Herding includes pastoral indicators linked to the redistribution of human pressure: Artemisia, Cichorioideae, Plantago lanceolata type, Plantago major/media type, Polygonum aviculare type, Rumex, Trifolium type, Urtica, Vicia type. 3) Fast Succession comprises indicators of relatively recent reforestation of cultivated land after abandonment: Alnus, Betula, Corylus, Ericaceae, Fraxinus ornus, Juniperus, Picea, Pinus, Populus, deciduous Quercus, Rosaceae. 4) Slow Succession includes indicators of secondary succession established after several decades of abandonment: Abies, Carpinus betulus, Fagus, Fraxinus, Ostrya/Carpinus orientalis, Quercus ilex type.

In order to validate the indicators overcoming the regional limits of Ellenberg values, a different subdivision has been provided following the Niinemets and Valladares shade tolerance scale for woody species of the Northern Hemisphere ${ }^{71}$. The subdivision of taxa in the Fast and Slow succession indicators remains the same with only three changes: Fraxinus ornus and Picea move from Fast to Slow succession and Fraxinus from Slow to Fast succession. Extended Data Fig. 1 and 2 show that the two groupings yield the same results, which confirms the reliability of our indicators. There is only one clear exception (Russia), with one more region where smaller-scale diversion occurs for only one indicator, 
Slow Succession (Norway). The different indicator behaviour results from the different attribution of Picea in our two sets of succession indicators: at high latitude, Picea characterizes the final stage of the ecological succession and hence its different attribution results in different summary indicator values in Russia for the two stages of ecological succession, fast and slow.

Please note our summary indicators are not designed to reflect the entirety of the landscape and reconstruct all of its different components. Rather, they are a means of approximating changes in the landscape related to the types of human activities, and their intensity, as much as they relate to demographic changes in human populations using and inhabiting these landscapes.

\section{BDP analytical methods: statistical and spatial}

To control for local specificity, pollen percentages of every taxon from each pollen site were standardised. From the taxa percent in a given year the arithmetic mean calculated for the observations from the period 1250-1450 was subtracted and the result divided by the standard deviation for the 1250-1450 period. Standardized taxa results were assembled for each site into four BDP summary indicators. Since each indicator has different numbers of taxa, the sum of standardized taxa values calculated for a given year and site was divided by the number of taxa in the indicator. For the purposes of replication, this standardised pollen dataset, comprising the four indicators for each sample from each site, is available as Supplementary Data 1.

This dataset has been analysed in two ways, statistically and spatially.

For the statistical approach, standardized regional indices of landscape transformation were created for each region by calculating the average value for all sites within the region, for each of the subperiods analysed in the study (1250-1350 and 1351-1450; 1301-1350 and 1351-1400; 1325-1350 and 13511375). Differences between means for each subperiod were measured by the use of the bootstrapping based on 10,000 resamples. The $90 \%$ and $95 \%$ confidence intervals were estimated with the biascorrected and accelerated method $(\mathrm{BCa})^{72}$. These results are visualized in Fig. 3 for the comparison of the sub-periods of 1250-1350 vs 1351-1450, and in Extended Data Fig. 7 and 9 for the comparison of the sub-periods of $1300-1350$ vs $1351-1400$ and $1325-1350$ vs 1351-1375, respectively.

For the spatial approach, we employed the Bayesian model AverageR developed within the Pandora \& IsoMemo initiatives (https://pandoraapp.earth/) to map the distribution of pollen indices across Europe. Average $R$ is a generalized additive model that has been previously described ${ }^{73}$. It relies on a thin plate regression spline ${ }^{75}$ to predict new, unseen data using the following model:

Yi $=g($ longitude,latitude $)+\varepsilon i$

where

Yi: independent variable for site i 
g(longitude, latitude): spline smoother

$\varepsilon \mathrm{i} \sim \mathrm{N}(0, \sigma \varepsilon)$ : error term

The spline smoother can be written as $X \star \beta$ where $X$ is a fixed design matrix and $\beta$ is the parameter vector. Surface smoothing is controlled by employing a Bayesian smoothing parameter estimated from the data and trades-off bias against variance to make the optimal prediction ${ }^{75}$. This parameter $\beta$ is assumed to follow a normal distribution: $\beta \sim N\left(0,1 / \delta^{*} \lambda{ }^{*} \mathrm{P}\right)$, where $\mathrm{P}$ is a so-called penalty matrix of the thin plate regression spline, which penalizes second derivatives ${ }^{75}$. The $\delta$ parameter is by default set to 1 but this can be adjusted to suit smoothing needs for each application. In our study $\delta$ was set at 0.9 to match the preferred spatial scale of analysis for our dataset (c. 250 to $500 \mathrm{~km}$ ).

AverageR was employed to generate smoothed surfaces for three sets of temporal bins (1250-1350 vs 1351-1450, as well as 1300-1350 vs 1351-1400 and 1325-1350 vs 1351-1375) and for the four BDP indicators (Extended Data Fig. 6, 8 and 10). For the same indicator the difference between the two temporal bins was plotted (Fig. 3; Extended Data Fig. 7 and 9).

Data Availability: All data generated or analysed during this study are included in this published article (as the Supplementary Data).

\section{References - methods}

45.

Ljungqvist, F. C. et al. Linking European building activity with plague history. Journal of Archaeological Science 98, 81-92 (2018).

46.

McConnell, J. R. et al. Pervasive Arctic lead pollution suggests substantial growth in medieval silver production modulated by plague, climate, and conflict. PNAS 116, 14910-14915 (2019).

47.

Izdebski, A. A rural economy in transition: Asia Minor from Late Antiquity into the Early Middle Ages. (Taubenschlag Foundation, 2013).

48.

Roberts, N. et al. Europe's lost forests: a pollen-based synthesis for the last 11,000 years. Scientific Reports 8, 716 (2018).

49. 
Bevan, A. et al. The changing face of the Mediterranean - Land cover, demography and environmental change: Introduction and overview. The Holocene 095968361982668 (2019)

doi:10.1177/0959683619826688.

50.

Yeloff, D. \& Van Geel, B. Abandonment of farmland and vegetation succession following the Eurasian plague pandemic of ad 1347-52. Journal of Biogeography 34, 575-582 (2007).

51.

Razi, Z. Life, marriage, and death in a medieval parish: economy, society, and demography in Halesowen, 1270-1400. (University Press, 1980).

52.

DeWitte, S. N. Age Patterns of Mortality During the Black Death in London, A.D. 1349-1350. J Archaeol Sci 37, 3394-3400 (2010).

53.

Broadberry, S. N. British economic growth, 1270-1870. (University Press, 2015).

54.

Cortonesi, A. L'agricoltura italiana fra XIII e XIV secolo: vecchi e nuovi paesaggi. in Medioevo delle campagne: rapporti di lavoro, politica agraria, protesta contadina. (eds. Cortonesi, A. \& Piccinni, G.) 1556 (Viella, 2011).

55.

Abel, W. Agrarkrisen und Agrarkonjunktur. Eine Geschichte der Land- und Ernährungswirtschaft Mitteleuropas seit dem hohen Mittelalter. (Parey, 1978).

56.

Fyfe, R. et al. The European Pollen Database: past efforts and current activities. Vegetation History and Archaeobotany 18, 417-424 (2009).

57.

Kuneš, P., Abraham, V., Kovář́k, O., Kopecký, M., \& PALYCZ contributors. Czech Quaternary Palynological Database - PALYCZ: review and basic statistics of the data. Preslia 81, 209-238 (2009).

58. 
Florenzano, A., Marignani, M., Rosati, L., Fascetti, S. \& Mercuri, A. M. Are Cichorieae an indicator of open habitats and pastoralism in current and past vegetation studies? Plant Biosystems - An International Journal Dealing with all Aspects of Plant Biology 149, 154-165 (2015).

59.

Smit, A. A scanning electron microscopical study of the pollen morphology in the genus Quercus. Acta Botanica Neerlandica 22, 655-665 (1973).

60.

Ellenberg, H. et al. Zeigerwerte von Pflanzen in Mitteleuropa. Scripta Geobotanica 18, 1-258 (1992).

61.

Dzwonko, Z. Assessment of light and soil conditions in ancient and recent woodlands by Ellenberg indicator values. Journal of Applied Ecology 38, 942-951 (2001).

62.

Diekmann, M. \& Lawesson, J. E. Shifts in ecological behaviour of herbaceous forest species along a transect from northern central to North Europe. Folia Geobotanica 34, 127-141 (1999).

63.

Gégout, J.-C. \& Krizova, E. Comparison of indicator values of forest understory plant species in Western Carpathians (Slovakia) and Vosges Mountains (France). Forest Ecology and Management 182, 1-11 (2003).

64.

Hájková, P., Hájek, M., Apostolova, I., Zelený, D. \& Dítě, D. Shifts in the ecological behaviour of plant species between two distant regions: evidence from the base richness gradient in mires. Journal of Biogeography 071103055558002-??? (2007) doi:10.1111/j.1365-2699.2007.01793.x.

65.

Wasof, S. et al. Ecological niche shifts of understorey plants along a latitudinal gradient of temperate forests in north-western Europe. Global Ecology and Biogeography 22, 1130-1140 (2013).

66.

Hill, M., Mountford, J., Roy, D. \& Bunce, R. Ellenberg's indicator values for British plants. ECOFACT Volume 2 Technical Annex. (Institute of Terrestrial Ecology, 1999).

67. 
Chytrý, M., Tichý, L., Dřevojan, P., Sádlo, J. \& Zelený, D. Ellenberg-type indicator values for the Czech flora. Preslia 90, 83-103 (2018).

68.

Böhling, N., Greuter, W. \& Raus, T. Zeigerwerte der Gefäßpflanzen der Südägäis (Griechenland). Indicator values of the vascular plants in the Southern Aegean (Greece). Braun-Blanquetia 32, 1-106 (2002).

69.

Pignatti, S., Menegoni, P. \& Pietrosanti, S. Biondicazione attraverso le piante vascolari. Valori di indicazione secondo Ellenberg (Zeigerwerte) per le specie della Flora d'Italia. Braun-Blanquetia 39, 1-97 (2005).

70.

Diekmann, M. Use and improvement of Ellenberg's indicator values in deciduous forests of the Boreonemoral zone in Sweden. Ecography 18, 178-189 (1995).

71.

Niinemets, Ü. \& Valladares, F. Tolerance to Shade, Drought, and Waterlogging of Temperate Northern Hemisphere Trees and Shrubs. Ecological Monographs 76, 521-547 (2006).

72.

Hall, P. Theoretical Comparison of Bootstrap Confidence Intervals. The Annals of Statistics 16, 927-953 (1988).

73.

Cubas, M. et al. Latitudinal gradient in dairy production with the introduction of farming in Atlantic Europe. Nature Communications 11, 2036 (2020).

74.

Wood, S. N. Thin plate regression splines. Journal of the Royal Statistical Society: Series B (Statistical Methodology) 65, 95-114 (2003).

75.

Groß, M. Modeling body height in prehistory using a spatio-temporal Bayesian errors-in variables model. AStA Adv Stat Anal 100, 289-311 (2016).

\section{Figures}




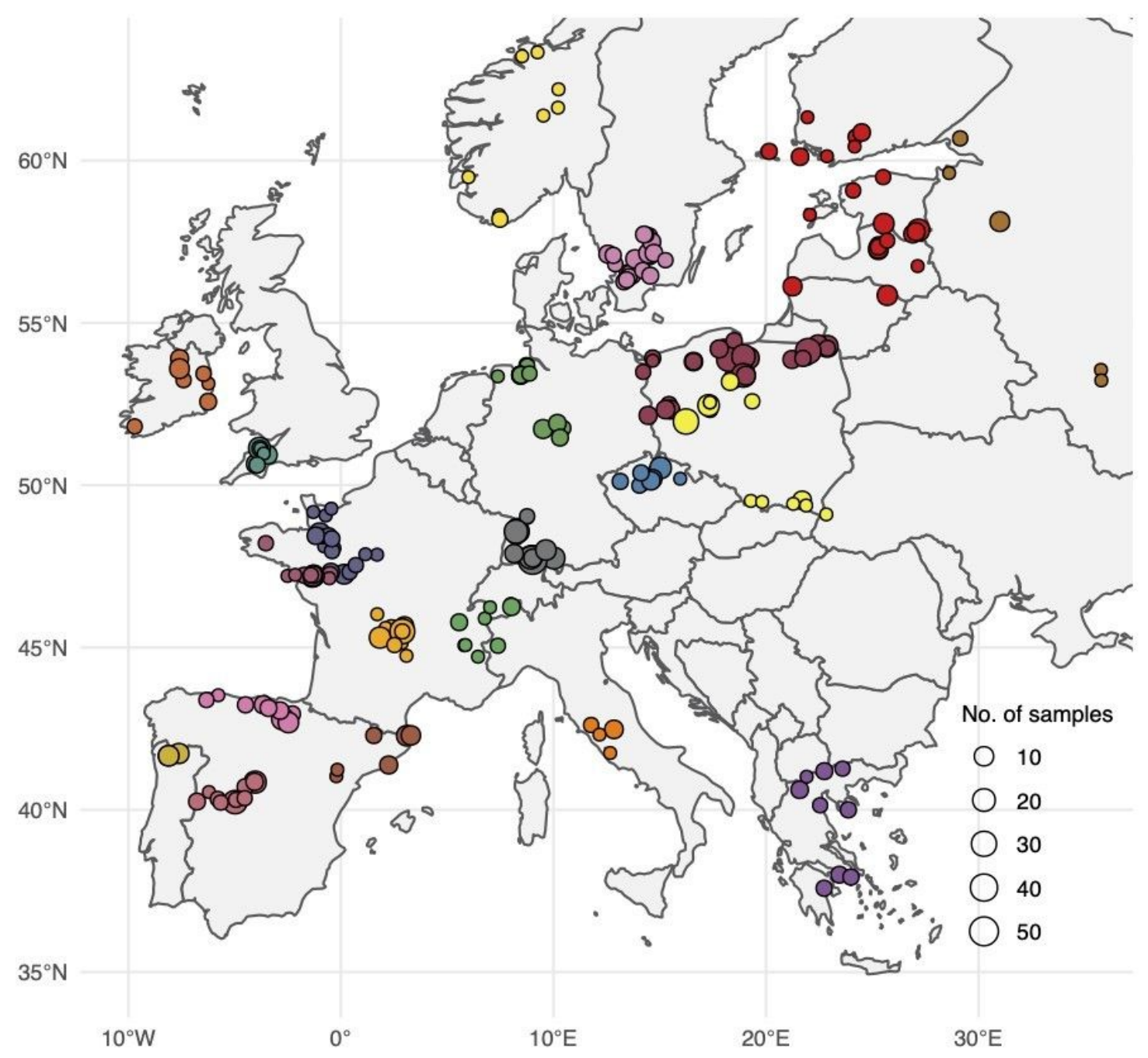

Figure 1

Location of pollen-analysed sediment cores used in this study. Circle size reflects the number of samples per site for the period of 1250-1450 CE, different colours reflect division of sites into regional clusters for the purpose of the analysis presented in Figure 3. 


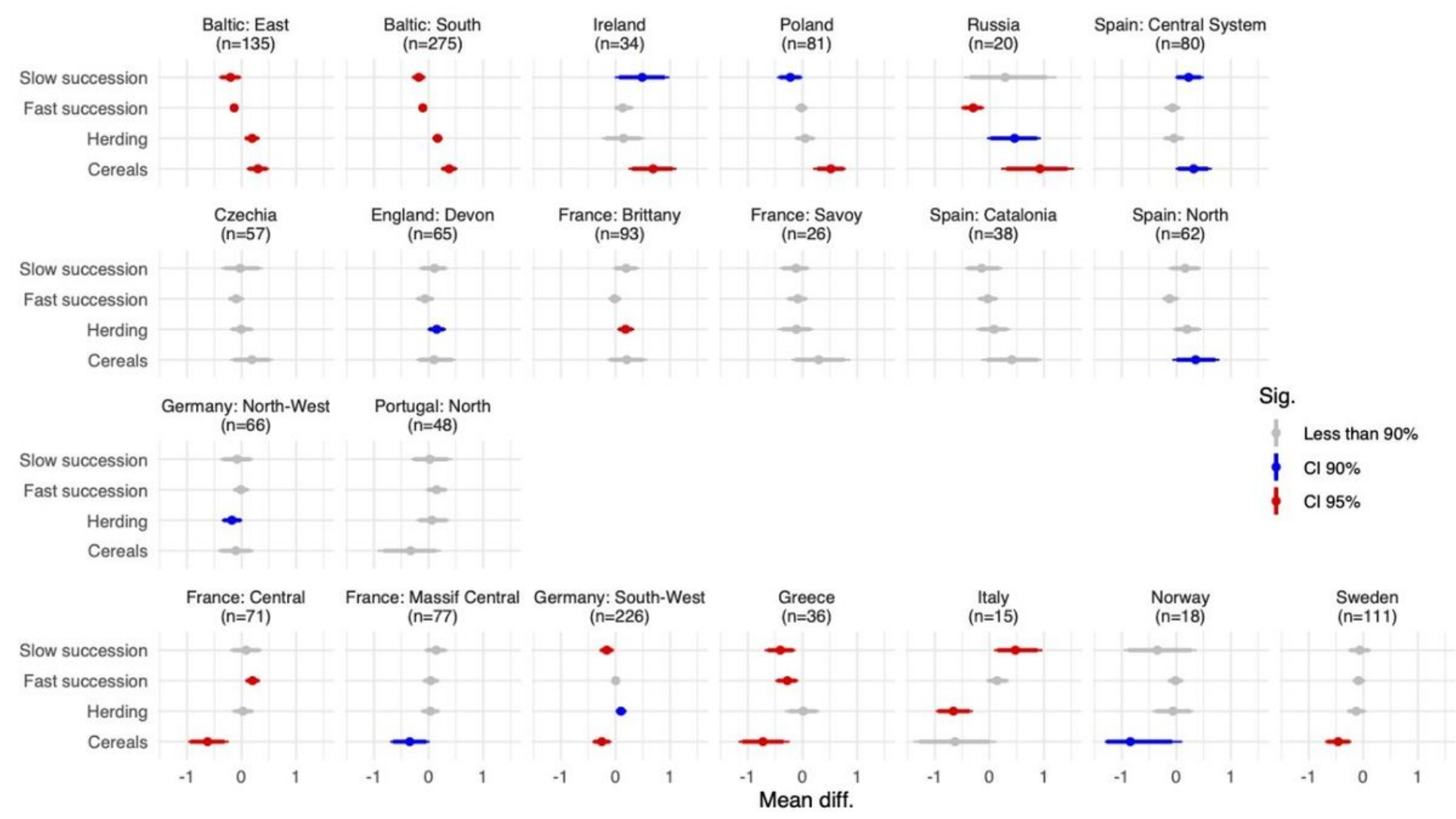

Figure 2

Post-Black Death regional-scale changes in four BDP pollen indicators. Difference between the means of 100-yr periods of 1250-1350 and 1351-1450 CE, with the standard deviation. Statistical significance is based on bootstrap estimates. The indicators are presented in four rows from statistically significant increases in standardised mean percentages of cereal pollen (top) to statistically significant declines in standardised mean percentages of cereal pollen (bottom). 
Cereal difference: 1250 to $1350 \mathrm{CE}$ vs. 1351 to $1450 \mathrm{CE}$

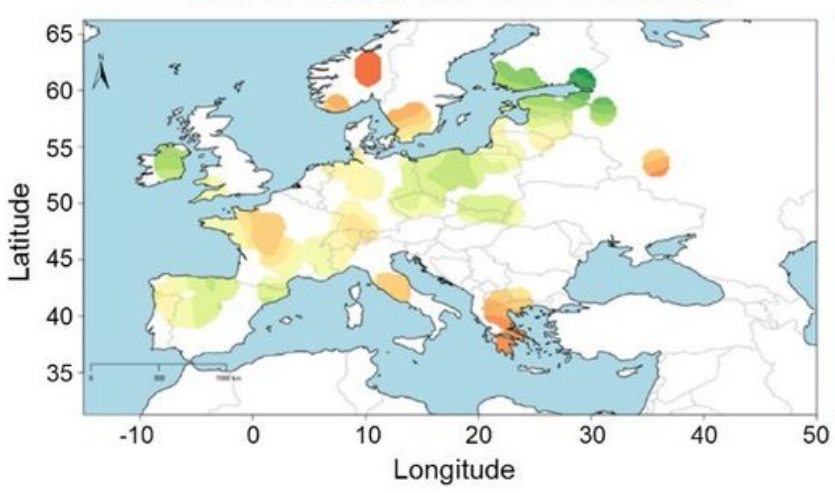

C

Fast Succession difference: 1250 to $1350 \mathrm{CE}$ vs. 1351 to $1450 \mathrm{CE}$

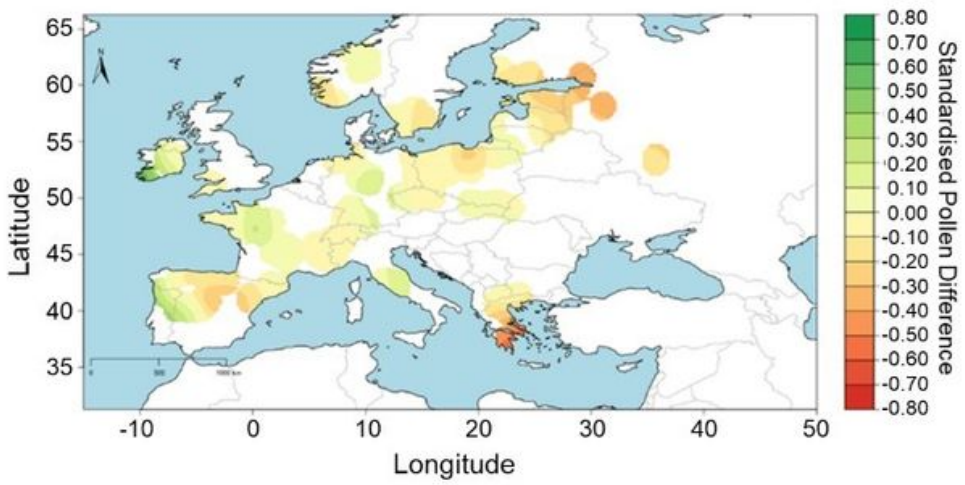

b

Herding difference: 1250 to $1350 \mathrm{CE}$ vs. 1351 to $1450 \mathrm{CE}$

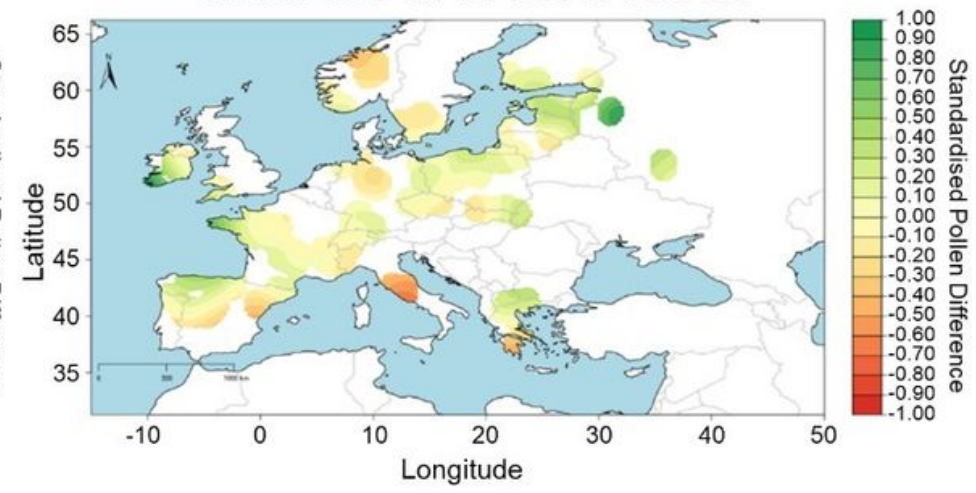

d

Slow Succession difference: 1250 to $1350 \mathrm{CE}$ vs. 1351 to $1450 \mathrm{CE}$

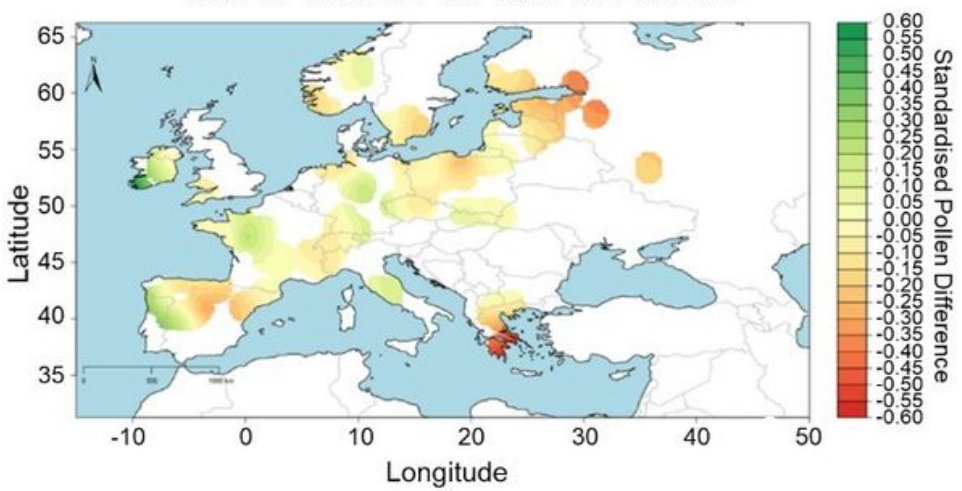

Figure 3

Spatial extrapolation showing 1250-1350 CE versus 1351-1450 CE temporal variation in the BDP pollen indicators a) Cereal b) Herding c) Fast Succession d) Slow Succession. Based on results from Extended Data Fig. 6. 


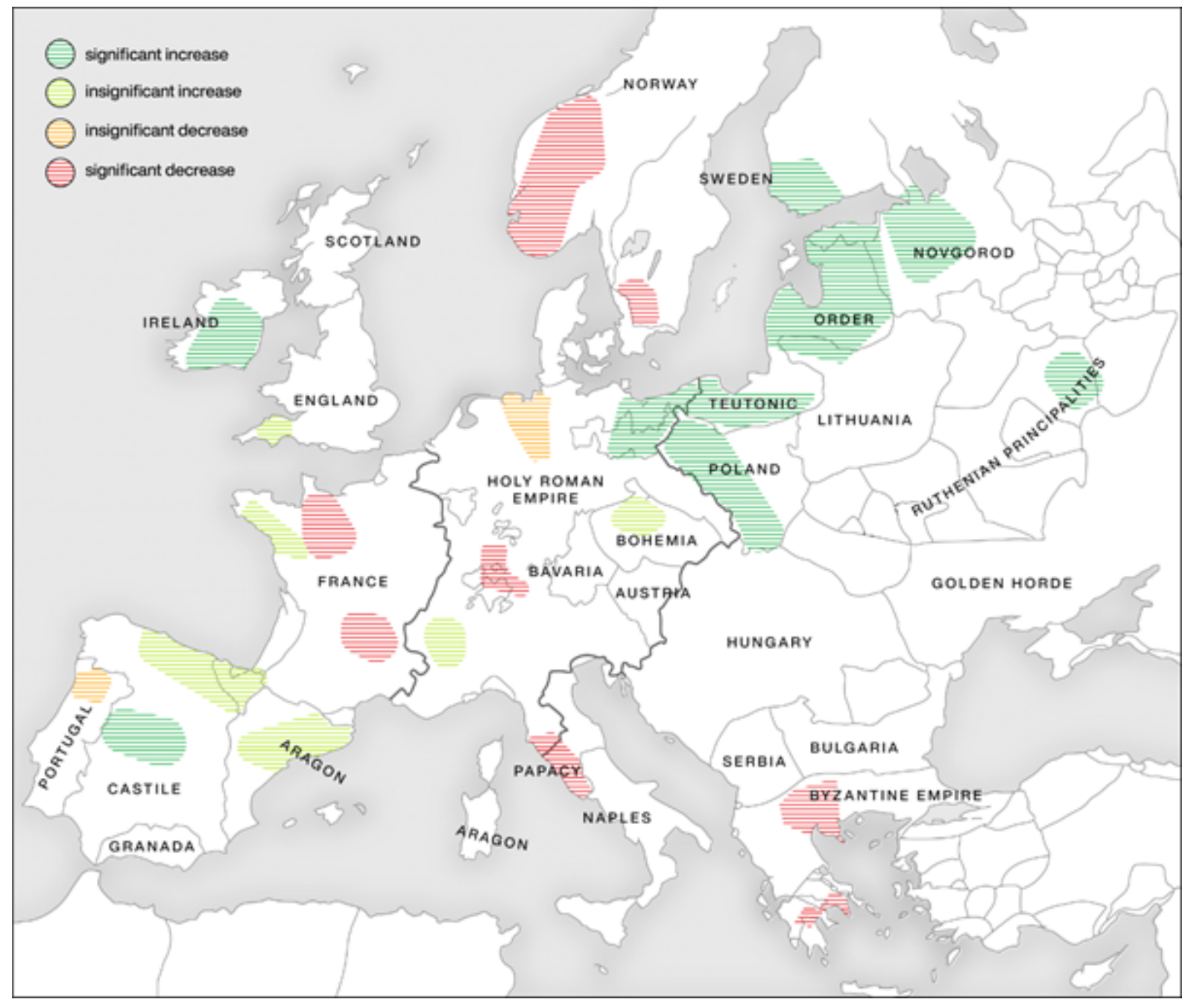

\section{Figure 4}

BDP-determined regional scenarios of Black Death demographic impact. Colours reflect centennial-scale changes in the cereal pollen indicators from Fig. 2. Background map with political borders of 14th-c. Europe (@Hans Sell, Michelle O’Reilly, Adam Izdebski, MPI SHH).

\section{Supplementary Files}

This is a list of supplementary files associated with this preprint. Click to download.

- SIGuide.docx

- SupplementaryData1.xlsx

- SupplementaryData2.pdf

- ExtendedDataFigures.docx 